\title{
Changes in THE MATHEMATICS LeARning Process DURING THE COVID-19 PANDEMIC AT JUNIOR HIGH SCHOOL IN BUKITTINGGI
}

\author{
Pipit Firmanti \\ Institut Agama Islam Negeri (LAIN) Bukittinggi, Indonesia \\ E-mail:firmantiyuberta@gmail.com \\ Fauzi Yuberta \\ Institut Agama Islam Negeri (LAIN) Bukittinggi, Indonesia \\ E-mail:faurijuberta@gmail.com
}

\begin{abstract}
(c) (i) (2)
(C2021 by the authors. Submitted for possible open access publication under the terms and conditions of the Creative Commons Attribution (CC-BY-SA) license (https://creativecommons.org/licenses/by-sa/4.0/) do) DOI : http://dx.doi.org/10.30983/educative.v6i1.4459

\begin{tabular}{l|l|l} 
Submission : June 06, 2021 & Revised: July 30, 2021 & Published : July 31, 2021
\end{tabular}

Abstract

The spread of Covid-19 has affected every sector, including education. The learning process that used to take place in the classroom has now become virtualized. However, this exacerbates pupils' difficulties in learning mathematics, which they previously considered challenging even in offline learning activities. To deal with this challenge, it is vital to describe alterations in the learning process under this pandemic situation. This qualitative research was carried out through interviews and questionnaires. The participants were seven teachers and seven students from various junior high schools in Bukittinggi with varying accreditation. Structured interviews, both online and in-person, were used to collect data. The result shows that students could understand the subject better before the pandemic. During the pandemic, the percentage of students who understood the material learning decreased by $10 \%$. However, the percentage of people who use online media as a learning resource has increased by $50 \%$. Overall, the assessment done by teachers on the cognitive aspects of a pandemic by Minimum Completeness Criteria (MCC) remains at 75. In the future, there will be a trend toward the use of e-learning and the development of technology-based learning media in the classroom.
\end{abstract}

Keywords: mathematics learning, Covid-19, online learning process

\section{Abstrak}

Penyebaran wabah Pandemi Covid-19 telah berdampak pada semua sektor termasuk pendidikan. Proses pembelajaran yang awalnya berlangsung tatap muka sekarang beralih secara virtual. Padahal sebelum pembelajaran daring dimulai, siswa masib kesulitan dalam mempelajari matematika. Oleh karena itu, mendeskripsikan perubahan apa saja yang ada selama proses pembelajaran daring penting dilakukan untuk mengatasi masalah ini Penelitian ini merupakan penelitian kualitatif dimana sampel diambil adalah tujuh orang guru dan tujuh orang siswa SMP/MTsN dari sekolah yang memiliki akreditasi berbeda di Bukittinggi. Pengambilan data dilakukan dengan wawancara terstruktur via online dan tatap muka. Berdasarkan hasil penelitian diperoleh: siswa lebih mudah memahami materi pelajaran yang disampaikan oleh guru sebelum pandemi. Persentase dalam pemahaman siswa terhadap materi yang diajarkan guru turun sebanyak. 10 $\%$ selama pandemi. Sebaliknya, persentase dalam penggunaan media online sebagai sumber belajar meningkat sebanyak. $50 \%$. Secara keseluruban, penilaian yang dilakukan guru cenderung pada aspek kognitif selama pandemi dengan Kriteria Ketuntasan Minimum (KKM) tetap 75. Dimasa yang akan datang, akan ada tren penggunaan e-learning di sekolah dan pengembangan media pembelajaran berbasis teknologi.

Kata kunci: pembelajaran matematika, Covid-19, proses pembelajaran daring

\section{Introduction}

A curriculum is a collection of learning materials and instructional programs that are delivered to pupils over the course of a single educational period. The curriculum design considers the conditions and abilities of students in the field of study. The current curriculum is also impacted by the Covid-19 situation. In addition, the virus is rapidly 
spreading around the globe. ${ }^{1}$ On March 11, 2020, the World Health Organization (WHO) declared the Coronavirus as a global pandemic. ${ }^{2}$ Indonesia is also affected by the virus at this moment.

Mathematics learning, which usually takes place in the classroom, now has to be learned virtually. Teachers are required to be able to use online media as a new strategy during online learning. In Indonesia, there is an effect on selfregulation of elementary school students who use learning videos during the pandemic ${ }^{3}$ Moreover, the international students' perception towards online learning agreed that online learning using the Tencent Meeting made the learning process well managed; the Tencent meeting was easy to use and affordable to learn. ${ }^{4}$ It seems that the mathematics teachers around the world have put their efforts to change their teaching strategies. ${ }^{56}{ }^{7}$ This shows that there is a significant influence on the learning process in various countries during the Covid-19 period.

In general, Indonesian schools implement the 2013 curriculum which was revised before the current situation changes the education system. This curriculum focuses on the acquisition of certain competencies by

${ }^{1}$ Said Nadeem, 'Coronavirus Covid-19: Available Free Literature Provided By Various Companies, Journals and Organizations Around the World', Journal of Ongoing Chemical Research, 5.1 (2020), 7-13 <https://doi.org/10.5281/zenodo.3722904>.

2 Domenico Cucinotta and Maurizio Vanelli, 'WHO Declares COVID-19 a Pandemic', Acta Biomedica, 91.1 (2020), 157-60

<https://doi.org/10.23750/abm.v91i1.9397>

3 Tommy Tanu Wijaya, Zhou Ying, and Lin Suan, 'Gender and Self Regulated Learning During Covid-19 Pandemic in Indonesia', Jurnal Basicedu, 4.3 (2020), 725$32<$ https://doi.org/10.31004/basicedu.v4i3.422>.

$4 \mathrm{H}$. Wiranota and T. T. Wijaya, 'The International Students' Perception towards Online Learning Using the Tencent Meeting during Covid-19 Outbreak', Journal of Physics: Conference Series, 1823.1 (2021) $<$ https://doi.org/10.1088/17426596/1823/1/012011>.

${ }^{5}$ Yusuke Uegatani, Nagisa Nakawa, and Masato Kosaka, 'Changes to Tenth-Grade Japanese Students' Identities in Mathematics Learning During the Covid-19 students. In this case, competence is defined as knowledge, skills, and abilities that are controlled by someone who has become part of him so that he is capable of performing optimal cognitive, affective, and psychomotor activities behavior. $^{8}$

Education that is only concerned with assessment will experience setbacks from time to time. ${ }^{9}$ Hence, the learning process is not only emphasized on one aspect but also the balance on the affective, psychomotor and cognitive aspects. The learning process that implements the scientific approach will combine these three aspects. The affective domain uses the transformation of the substance or teaching material so that students "know why". The psychomotor domain of uses the transformation of substance or teaching materials so that student's "know-how". The cognitive domain is non-physical ${ }^{10}$ using the transformation of the substance or teaching material so that students "know what".

In addition, the implementation of the 2013 curriculum is expected will produce productive, creative, innovative, and effective generations through strengthening attitudes, skills, and knowledge integration. The 2013 curriculum allows teachers to assess student

Pandemic', International Electronic Journal of Mathematics Education, 16.2 (2021), em0638.

$6 \mathrm{Z}$ Cakir and H B Savas, 'A Mathematical Modelling Approach in the Spread of the Novel 2019 Coronavirus SARS-CoV-2 (Covid-19) Pandemic. Electron J Gen Med. 2020; 17 (4): Em205', 2020.

7 Rajapandian Radha and others, 'E-Learning during Lockdown of Covid-19 Pandemic: A Global Perspective', International Journal of Control and Automation, 13.4 (2020), 1088-99.

8 Mulyasa, Pengembangan Dan Implementasi Kurikulum 2013 (Bandung: PT Remaja Rosdakarya, 2013).

9 Toipur, 'Pentingnya Penilaian Kemampuan Matematika yang berbasis pada Proses Pembelajaran', Jurnal Math Educator Nusantara, 03.76 (2017), 1-57.

10 Triwahyu Riyatuljannah and Suyadi Suyadi, 'Analisis Perkembangan Kognitif Siswa pada Pemahaman Konsep Matematika Kelas V Sdn Maguwoharjo 1 Yogyakarta', EduHumaniora | Jurnal Pendidikan Dasar Kampus Cibiru, 12.1 (2020), 48-54 $<$ https://doi.org/10.17509/eh.v12i1.20906>. 
learning outcomes in the process of achieving learning goals, which reflects mastery and understanding of what is learned. However, during the Covid-19 Pandemic, schools experienced various obstacles in implementing this curriculum. ${ }^{11}$

Based on the official letter of the ministry of education and culture No. 3 of 2020 regarding the prevention of the spread of Covid-19 in education units, schools need to consult with the local education office whether teaching and learning activities need to be temporarily closed, so that students follow the online learning process (Kemendikbud, 2020). Bukittinggi began to close learning at schools starting on March 19, 2020. Then, on November 19, 2020, they began to do normal activities at school as usual by health protocols. Although students do not attend school every day, online learning is nevertheless used. This learning process occurs online, using the internet network, rather than face-to-face between teachers and students. Students study completely from home for around eight months. In accordance with this, Siahaan (in Khatimi) states that there are three alternative models of learning activities that the students can choose, as follows: (i) direct learning in the classroom (face-to-face), (ii) partly direct learning and others via the internet, (iii) entirely via the internet ${ }^{12}$

Most schools implement a reduced-hours emergency curriculum. This condition has an impact on the pupils' ability to comprehend and accept the teacher's material. Online mathematics learning elicited diverse reactions

${ }^{11}$ Gita Kencanawaty, Chatarina Febriyanti, and Ari Irawan, 'Tantangan dan Strategi Pembelajaran Matematika di Masa Adaptasi Kebiasaan Baru (AKB) Dampak dari Covid-19', Prosiding Seminar Nasional Dan Diskusi Panel Pendidikan Matematika, 58, 2020, 215-20.

12 Husnul Khatimi, 'Mengenal E-Learning Sebagai Salah Satu Bentuk Kegiatan Pembelajaran', Info Teknik, 7.2 (2006), 72-81.

${ }^{13}$ Lissya Whildan, 'Analisis Teori Perkembangan Kognisi Manusia menurut Jean Piaget', Permata: Jurnal Pendidikan Agama Islam, 2.1 (2021), 11-22. from society, particularly from the parents of the students.

Therefore, the process of learning mathematics that switches from direct to online learning will create more problems that must be solved. Mathematics had been previously assumed to be a subject feared by students. Mathematics must be taught from concrete to abstract concepts because children's ability to understand the material is adjusted to their cognitive development. Based on Piaget's theory of cognitive development there are four stages, namely sensorimotor, preoperational, concrete operations, and formal operations. ${ }^{1314}$ Children aged 6 to 12 years are in the concrete operational stage. They can already develop the ability to retain, group adequately, sort, and handle the concept of numbers. ${ }^{15}$ In formal operations, children begin to involve logic reasoning which appears at the age of eleven to fifteen years. In Indonesia, this stage begins to emerge when children enter junior high school.

Before online learning began, students had already got difficulties in learning mathematics. This is because mathematics is dominated by abstract concepts that make it difficult for students to understand. Teachers are not able to teach mathematics material directly to the discussion of formulas because the concepts are abstract. Cognitive psychology has described some of the best ways to develop the learning experience of mathematics. The first is to build basic mathematical concepts using manipulatives, the second is to connect their knowledge by making mathematical notations with mathematical operations, and the third is

${ }^{14}$ Leny Marinda, 'Teori Perkembangan Kognitif Jean Piaget dan Problematikanya pada Anak Usia Sekolah Dasar', An-Nisa': Jurnal Kajian Perempuan Dan Keislaman, $\quad 13.1 \quad$ (2020), $116-52$ <https://doi.org/10.35719/annisa.v13i1.26>.

15 Ridho Agung Juwantara, 'Analisis Teori Perkembangan Kognitif Piaget pada tahap Anak Usia Operasional Konkret 7-12 Tahun Dalam Pembelajaran Matematika', Al-Adrka: Jurnal Ilmiah Pendidikan Guru $\begin{array}{llll}\text { Madrasab Ibtidaiyah, } & 9.1 & \text { (2019), } & 27\end{array}$ <https://doi.org/10.18592/aladzkapgmi.v9i1.3011>. 
to understand and apply their knowledge independently. ${ }^{16}$

Based on research conducted by Indrie on 32 junior high school students in Karawang Regency, it can be seen that $41.18 \%$ of male students and $53.33 \%$ of female students are just at the initial formal operation stage. While the rest are in the concrete stage. ${ }^{17}$ The number of students who are at concrete level shows that the mathematics learning process has not been maximized in the classroom. Moreover, the results of research conducted on class VIII students at one of the public junior high schools in Purwakarta before Covid-19, showed that students still had difficulties in working on the five questions given. In general, students can only answer two questions correctly. It is suggested that the learning process should use strategies so that students' mathematical critical thinking skills are increasing. ${ }^{18} \mathrm{On}$ the other hand, the current online learning process adds to the long list of existing problems.

Furthermore, research conducted by Gita, et al (2020) revealed that the challenges faced by mathematics teachers included their readiness to present virtual learning with the constraints of teachers' limitations in using technology and internet access, which sucked up a significant amount of quota when using virtual meetings through a Zoom Meeting. ${ }^{19}$ The strategy used by the teacher is to make teaching videos related to teaching materials and then distribute them to students through Whatsapp Groups.

16 Arni Kholiyanti, 'Pembelajaran Matematika dari Konkrit ke Abstrak dalam Membangun Konsep Dasar Geometri bagi Siswa Sekolah Dasar', Pi: Mathematics Education Journal, 1.2 (2018), 40-46 $<$ https://doi.org/10.21067/pmej.v1i2.2322>.

${ }^{17}$ Indrie Noor Aini and Nita Hidayati, 'Tahap Perkembangan Kognitif Matematika Siswa SMP Kelas VII Berdasarkan Teori Piaget ditinjau dari Perbedaan Jenis Kelamin', Jurnal Penelitian Dan Pembelajaran Matematika, $\quad 10.2 \quad$ (2017), $\quad 2-7$ <https://doi.org/10.30870/jppm.v10i2.2027>.
The traditional representation of a didactic system in mathematics education as a triangle: teacher, learner, knowledge. Nowadays, it become four components that can be distinguished in a didactic system involving any technological tool, namely the tool, some knowledge, student(s) and a teacher, and the inevitable relationships between these poles. ${ }^{20}$ This shows that technology in learning mathematics is very influential.

Meanwhile, preliminary studies at several Bukittinggi junior high schools revealed that teachers recognized a variety of talents and attitudes among students before the epidemic, including performing work, making space, drawing graphs, manipulating skills, communicating, and others. The teachers were impressed by the students' ability to draw number lines for 'integral' and arrow and cartesian diagrams for 'function.' Teachers, on the other hand, only use portfolios after the pandemic, and assessments are primarily cognitive.

The teachers assessed students based on competency characteristics and giving written tests to see the accuracy and correctness of the image or graph before the pandemic. However, during online learning, it is very difficult to monitor and assess the students'. Therefore, the researchers would like to investigate the mathematics learning process of junior high school students in Bukittinggi, focusing solely on the cognitive aspect to describe the forms of change that occur during the online mathematics learning process.

18 Dara Puspita Dewi and others, 'Analisis Kemampuan Berpikir Kritis Matematis Siswa SMP pada Materi Lingkaran dan Bangun Ruang Sisi Datar', JPMI (Jurnal Pembelajaran Matematika Inovatif), 2.6 (2019), 371 <https://doi.org/10.22460/jpmi.v2i6.p371-378>.

${ }^{19}$ Kencanawaty, Febriyanti, and Irawan.

${ }^{20}$ Jana Trgalová, Alison Clark-Wilson, and HansGeorg Weigand, 'Technology and Resources in Mathematics Education', Developing Research in Mathematics Education, 2018, 142-61 <https://doi.org/10.4324/9781315113562-12>. 


\section{Research Method}

This study used a qualitative approach. According to Bogdan and Tylor, qualitative research is a research procedure that produces descriptive data in the form of written or spoken words from people and observable behavior. ${ }^{21}$ It answered research problems that require an in-depth understanding of a chosen object, to produce conclusions in the context of the time and situation concerned.

The participants in this study were seven teachers and seven students of junior high school/Islamic junior high school (SMP/MTsN) which have a different level (accreditation) in Bukittinggi. They were taken randomly. This research started from August to November 2020. Data collection was carried out directly in the form of structured interviews by a direct and online meeting. Valid interview guidelines were given to teachers, while closed questionnaires were given to students. There are 12 questions items in the interview guidelines.

Table 1. Interview guidelines for teacher

\begin{tabular}{cl}
\hline Code & \multicolumn{1}{c}{ Question } \\
\hline A & $\begin{array}{l}\text { When is your schedule for teaching math? in } \\
\text { a direct or online class? }\end{array}$ \\
\hline B & $\begin{array}{l}\text { Is the subject matter that you delivered can } \\
\text { be understood by students well? }\end{array}$ \\
\hline C & $\begin{array}{l}\text { What are the learning methods or strategies } \\
\text { that you use in learning mathematics? }\end{array}$ \\
\hline $\mathrm{D}$ & $\begin{array}{l}\text { What are the learnisng resources that you use } \\
\text { in learning mathematics? }\end{array}$ \\
\hline $\mathrm{E}$ & $\begin{array}{l}\text { How is the implementation of the Daily Test } \\
\text { (UH)? Is the form of the question given an } \\
\text { essay or objective? }\end{array}$ \\
\hline $\mathrm{F}$ & $\begin{array}{l}\text { What is the Minimum Completeness Criteria } \\
\text { (MCC) for student achieved that you take? }\end{array}$ \\
\hline $\mathrm{G}$ & $\begin{array}{l}\text { In the final assessment, what is the } \\
\text { proportion of the assessment taken from } \\
\text { UH, UTS and UAS that you give? }\end{array}$ \\
\hline $\mathrm{H}$ & $\begin{array}{l}\text { What are the obstacles that you face in the } \\
\text { process of delivering the material? }\end{array}$ \\
\hline $\mathrm{I}$ & $\begin{array}{l}\text { What have you done to overcome these } \\
\text { obstacles? }\end{array}$ \\
\hline $\mathrm{J}$ & $\begin{array}{l}\text { What kind of instructional media do you use } \\
\text { in the learning process? }\end{array}$ \\
\hline
\end{tabular}

${ }^{21}$ Nurul Zuriah, 'Metodologi Penelitian Sosial Dan Pendidikan’ (Jakarta: Bumi Aksara, 2006), p. 92.

\begin{tabular}{cl}
\hline $\mathrm{K}$ & $\begin{array}{l}\text { What obstacles did you find in assessing } \\
\text { students' skills in mathematics? }\end{array}$ \\
\hline $\mathrm{L}$ & $\begin{array}{l}\text { What kind of reward/punishment do you } \\
\text { give to a student? }\end{array}$ \\
\hline
\end{tabular}

Due to the availability of alternative answers, the surveys issued to students are closed questionnaires. The Guttman scale is utilized. This is based on the fact that the respondents were junior high school students who filled out the questionnaire. The presented questionnaire contains seven items. It can be seen as follows:

Table 2. Questionnaire for student

\begin{tabular}{clc}
\hline \multirow{2}{*}{ Code } & \multicolumn{1}{c}{ Question } & Answer \\
\cline { 2 - 3 } B & $\begin{array}{l}\text { I can understand the subject } \\
\text { matter that the teacher teaches } \\
\text { well }\end{array}$ \\
\hline $\mathrm{D} 1$ & $\begin{array}{l}\text { official books are used as } \\
\text { learning resources }\end{array}$ \\
\hline $\mathrm{D} 2$ & $\begin{array}{l}\text { Online media is used as a } \\
\text { learning resource }\end{array}$ \\
\hline $\mathrm{H}$ & $\begin{array}{l}\text { I have difficulty in doing } \\
\text { exercises given by a teacher }\end{array}$ \\
\hline $\mathrm{J}$ & $\begin{array}{l}\text { Teachers use media in the } \\
\text { learning process }\end{array}$ \\
\hline $\mathrm{K}$ & $\begin{array}{l}\text { The teacher guides me in } \\
\text { drawing graphs }\end{array}$ \\
\hline $\mathrm{L}$ & $\begin{array}{l}\text { The teacher gives punishment } \\
\text { to students who are not } \\
\text { disciplined }\end{array}$ \\
\hline
\end{tabular}

\section{Result}

There are two parts in this section. Firstly: The interviews were conducted with seven teachers from different schools in Bukittinggi. These schools have different accreditations. This focused on cognitive aspects. The results of the interviews obtained as follow:

Aspects of A: Tend not to change. The teachers have taught according to a predetermined schedule. However, the implementation is different. Before the pandemic it was conducted in a classroom; during the pandemic, it is done virtually (zoom, WA, google classroom, etc.). The fact shows that one school has reduced the class hours. Teachers who used to teach twice a week, have 
reduced the meeting to once a week during the pandemic

Aspect of B: All respondents stated that it was easier for students to understand the learning materials before the pandemic because the process was in the classroom. The students could directly ask the teacher if they did not understand the materials. Meanwhile, after the pandemic, not all of the material can be understood by students. Therefore, the students tend to cheat on their friends' answers.

Aspect of C: There has been a change in the teachers' learning strategy. They used a variety of learning models such as cooperative learning, discovery learning, problem-based learning, lectures, questions and answers, discussions, and others. However, during the pandemic, the average teachers use online media such as WhatsUp, video call, zoom, and google classroom.

Aspect of D: It did not significantly change. The learning resources used by teachers are still the same before and after pandemics such as textbooks, teaching materials, LKPD, and modules.

Aspect of E: Teacher gave examination (UH) directly using objective or essay test. An objective test consists of four choices with one correct answer. Therefore, a teacher can mark objectively. Meanwhile, essay test guides the student to develop their process of thinking. Some teachers combine both of these tests in giving the exam.

In general, the aspect of $F \& G$ did also not significantly changes. The Minimum Completeness Criteria (MCC) taken by every teacher also remains between before and after the pandemic, which is 75 . One school whose MCC is different for each grade and two schools take lower MCC. Furthermore, the proportion taken for the assessment also does not change before and after the pandemic. It depends on the policies of every school.

During the online class, teachers use google forms in giving exams. Google form is a service from Google that allows the student to create an answer to a given problem with online form features that can be customized according to your needs. Then, the teacher can get answers directly from pupils who took the examination.

Aspect of $\mathrm{H}$ : The obstacle faced by teachers in delivering material was the lack of student motivation in a direct meeting. The students' minds are indoctrinated because mathematics is a difficult subject. During the Covid-19, teachers are unable to explain in detail due to limited time and resources. Teachers also cannot directly identify students who do not understand because they cannot see their facial expressions. The students are also more comfortable asking friends compared to teachers during virtual class. In addition, some students do not study at all.

Aspect of I: The teachers have tried to overcome these obstacles. In a normal situation, they could suddenly give a quiz to the students and change the learning methods. In this new normal era, the teachers provide teaching materials by creating tutorial videos and implementing counseling services.

Aspect of J: The teachers rarely use learning media during the pandemic. The media used by the teachers are dominated by videos which are contrary to the various learning tools they used in a normal class situation.

Aspect of $\mathrm{K}$ : the teachers had limited time to notice student skills before the pandemic. The problem arises during the pandemic when they get difficulties monitoring the students' activities directly and the time to collect the assignments is not on time.

Aspect of B5: Teachers discuss the assignments with the students to ensure that they comprehend the solution. Teachers also give pupils advice and education, as well as a second opportunity if they are late in delivering tasks. Teachers would also call pupils one by one to school during the pandemic and ask them to transmit images of their notes and 
exercises to a private Whatsapp account to address students' different personalities.

Aspect of L: before the pandemic, the teacher gave punishment for students who did not do homework such as doing it or sitting in front of the classroom and memorizing the verses. During the online learning process, the teachers only ask the students to do and complete the assignments on time. During the pandemic, it is difficult to give punishment, but if the students do not practice too much, they will not be allowed to take the exam.

Secondly, the result of the questionnaire given to seven students can be seen as follow:

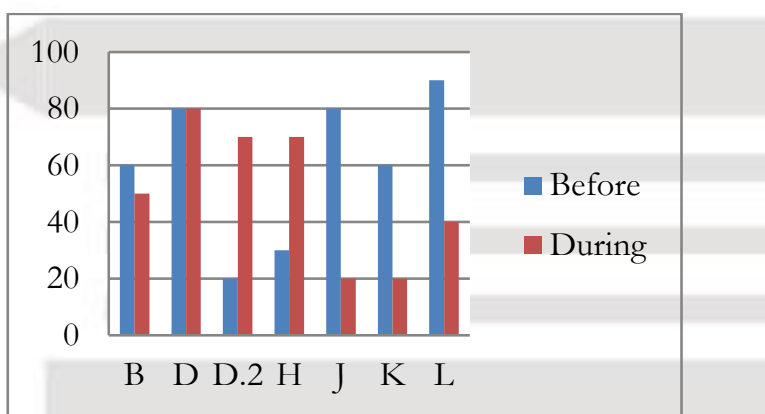

Figure 1. Percentage of student answer yes

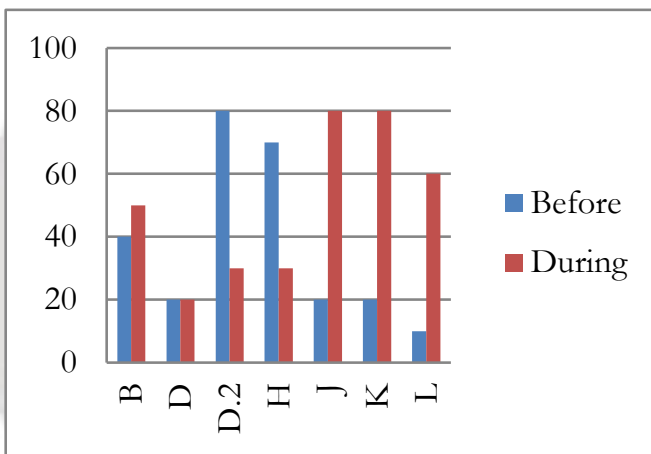

Figure 2. Percentage of student answer no

Note:

B: I can understand the subject matter that the teacher teaches well

D.1: official books are used as learning resources

D.2: Online media is used as a learning resource

$\mathrm{H}$ : I have difficulty in doing exercises given by the teacher

22 Muhammad Wildan Sahidillah and others, 'Whatsapp Sebagai Media Literasi Digital Mahasiswa', Pendidikan Bahasa Indondesia P, 2011, 52-57.

${ }^{23}$ Resa Iskandar, 'Penggunaan Grup Whatsapp Sebagai Media Pembelajaran terhadap Peserta Didik DTA At-Tawakal Kota Bandung', Comm-Edu (Community
$\mathrm{J}$ : Teachers use media in the learning process

$\mathrm{K}$ : The teacher guides me in drawing graphs

$\mathrm{L}$ : The teacher gives punishment to students who are not disciplined

Based on the graph above, it could be seen the decrease in students' ability to understand the material presented by the teacher when the pandemic is $10 \%$. Then, during the pandemic, there is a shift from $20 \%$ to $70 \%$ of people using online media as a learning resource. The percentage of people who use learning resources as books is around $80 \%$. From $30 \%$ to $7 \%$ of students find it difficult to work on the teacher's questions.

Furthermore, while $80 \%$ of students believe that teachers use teaching tools in the learning process, only $20 \%$ of teachers use them throughout the pandemic. During the pandemic, teachers assist pupils in generating graphs in proportions ranging from $60 \%$ to $20 \%$. In terms of the affective aspect, teachers punish students who are not disciplined at first by reducing their grades from $90 \%$ to $40 \%$. This is due to existing limitations.

\section{Discussion}

Before the Covid-19 pandemic, some teachers were already used WhatsApp as a learning media. ${ }^{22}{ }^{23}$ Hence, in this research, teachers generally use Whatsapp and google classroom media in the learning process. According to Indaryani and Suliworo, there are several benefits in using Whatsapp as a free application that is easy to use in the learning process including providing collaborative and collaborative online learning facilities between teachers and students or fellow students both at home and school and can be used to share comments, text, images, videos, sounds, documents. ${ }^{24}$

\footnotetext{
Education Journal), $3.2 \quad$ (2020), $\quad 97$ $<$ Https://Doi.Org/10.22460/Comm-Edu.V3i2.3778>.

${ }^{24}$ Eka Indaryani and Dwi Suliworo, 'Dampak Pemanfaatan WhatsApp dalam Meningkatkan Motivasi Belajar Siswa pada Pelajaran Fisika', Prosiding Seminar Nasional Quantum, 25 (2018), 25-31.
} 
Meanwhile, according to Sewang (in Melisa) Google Classroom is actually designed to facilitate the interaction of teachers and students in cyberspace. This is because, teachers have the flexibility of time to share material learning and give independent assignments to students. In addition, teachers can also open discussion rooms for students online. $^{25}$

The need for considering technologies within the full range of resources available for students, teachers and teacher educators such as software, computers, interactive whiteboards, online resources is becoming essential. ${ }^{26}$ In fact, the learning resources used by teachers are still the same before and after pandemics. Even though they should explore the use of technology as a learning resource.

The learning process using online media is called e-learning which will become a trend in the future. This is one of the impacts of the effect of covid-19 on the world of education. In more detail, this e-learning is an independent learning process that is facilitated and supported through the use of information and communication technology so that students can access it anytime from all over the world. ${ }^{27}$

Nowadays, e-learning functions as a substitute because e-learning is carried out as a substitute for learning activities that are entirely carried out via the internet. ${ }^{28}{ }^{29}$ Whatever alternative learning model will be chosen by students will not affect the assessment as the

25 Indah Melisa, 'Pengembangan Media Pembelajaran Berbasis E-Learning pada Mata Kuliah Perkembangan Peserta Didik di Jurusan Pendidikan Teknik Elektronika Universitas Negeri Makassar', Jurnal Program Studi Pendidikan Teknik Elektronika FT-UNM, 2019.

26 Trgalová, Clark-Wilson, and Weigand.

${ }^{27}$ Maspaeni, 'Penerapan Quality Control dalam Upaya Meningkatkan Kualitas Pendidikan Melalui ELearning', Jutisi, 6.1 (2017), 1311-1448.

${ }^{28}$ Nidaa Muhammad Baqer Al-Yasiri, 'Effects of Using E-Learning as a Substitute for Traditional Education in the Time of Corona', Turkish Journal of three models of presentation of teaching material have the same recognition or assessment. If the students can complete their coursework and graduate through conventional media or entirely via the internet, or even through a combination of these two models, the educational institution will give the same recognition. This flexible situation is considered to be very helpful for students to speed up the completion of their lectures. ${ }^{30}$

In fact, many students submit assignments not on time. This is because students still have difficulty understanding the material presented online dan their network. As we know that mathematics consist of abstract concepts ${ }^{31}$ which have need a clear explanation. Therefore, teacher calls them privately to go to school. When naughty students are called, they do not go to school. The teacher will usually trace it to his house and send the positive messages. Many obstacles were encountered in the completeness of documents and timeliness

Overall, e-learning is not fully maximized. Indonesian teachers in junior high school faced a great challenge in using e-learning as a tool of instruction during school closures as a result of the Covid-19 pandemic ${ }^{32}$ Therefore, it is hoped that in the future teachers can innovate learning strategies for the online meeting as e-learning technologies offer learners control over content, learning sequences, pace of learning, time, and often media, allowing them to tailor

Computer and Mathematics Education (TURCOMAT), 12.13 (2021), 3420-32.

${ }^{29}$ Emmanuel Aboagye, Joseph Anthony Yawson, and Kofi Nyantakyi Appiah, 'COVID-19 and E-Learning: The Challenges of Students in Tertiary Institutions', Social Education Research, 2021, 1-8.

${ }^{30}$ Khatimi.

${ }^{31}$ Kholiyanti.

32 Mailizar and others, 'Secondary School Mathematics Teachers' Views on e-Learning Implementation Barriers During the Covid-19 Pandemic: The Case of Indonesia', Eurasia Journal of Mathematics, Science and Technology Education, 16.7 (2020) $<$ https://doi.org/10.29333/EJMSTE/8240>. 
their experiences to meet their personal learning objectives ${ }^{33}$

Based on data result, online media is used as a learning resource increase $50 \%$ during pandemic. Consequently, teachers are required to be able to master technology and then develop strategies or learning models according to the characteristics of the student and learning material. There are differences in the cognitive development of students at each level of education. This is in line with the research that has been done by Piaget that cognitive development is universally applicable stages with different time limits. The age of students at this level is around 13-16 years in the Formal Operational stage. Children at this age think in a more abstract, logical and more idealistic way.

One example of a learning model that can be developed during the online learning process is the research conducted by Arta, et al (2020). They develop online learning mathematics based on a contextual approach for junior high school students. On the website that they have designed previously, several menus and features have been designed in a language that is interesting and easy for students to understand. In addition, the development of online learning adapted to the lesson plans based on seven main components of contextual approach looks as follows: constructivism, inquiry, asking, learning community, modeling, reflection, authentic assessment. ${ }^{34}$

Second example, teachers can use online learning media in the form of mathematics software as done by Wijaya et al. They used Hawgent dynamic mathematical software for teaching quadratic functions. ${ }^{35} \mathrm{It}$ is better than traditional teaching methods as students are

33 P. Sukaesih and E. Nugraha, 'Go-Study Electronic Learning Service Application', IOP Conference Series: Materials Science and Engineering, 407.1 (2018) $<$ https://doi.org/10.1088/1757899X/407/1/012036>.

34 Trianto ibnu badar Al-Tabany, 'Mendesain Model Pembelajaran Inovatif,Progresif,Kontekstual', 2017, 314 . able to easily visualize and generalize the graphical form of the quadratic equation. This automatically increases student's learning achievement and makes them find math interesting.

Based on the characteristics of the junior high school students, learning mathematics with existing mathematical symbols has been able to be accepted by students. That is, junior high school students already have the readiness to think more abstractly in accepting mathematical concepts. Therefore, in designing a learning teacher must pay attention to this condition. This is certainly not too difficult to apply to normal situations compared to the current situation. In general, teacher noticed attention to students' thinking and behavior such as style of communicating at school directly. Some teachers use journals and note rubrics as well.

However, during the pandemic, teachers can only see students by looking at the accuracy in the collection task on time. Teachers can not directly observe the faces of students who understand or not. The communication process takes place online. How do students work to answer the problem. Eventhough the teachers cannot see the actual behavior of students; the teachers look at from activity of students in greeting or answering teachers' question and provide reports on note in the WhatsApp group.

This is another reason that online learning that is carried out completely without two-way communication will make it difficult for students to understand the teaching material. Therefore, teachers are indeed required to be able to innovate in designing strategies or

35 Tommy Tanu Wijaya and others, 'Hawgent Dynamic Mathematic Software as Mathematics Learning Media for Teaching Quadratic Functions', Journal of Physics: Conference Series, $1592.1 \quad$ (2020) $<$ https://doi.org/10.1088/17426596/1592/1/012079> 
learning models that will be used in their respective classes.

\section{Conclusion}

Mathematics learning before and during the pandemic tends to be different. The changes are:

Many students are not focused during online learning and teacher cannot control the existing students one by one. Therefore, the percentage of students' understanding of the material learning decreased by $10 \%$ during pandemic. In addition, some schools reduce study time including mathematics and teacher teach by using zoom, whatssup group, google classroom during online class.

The percentage of using online media as a learning resource increased by $50 \%$. Therefore, there has been a change in learning strategies. In general, junior high school teachers in Bukittinggi have not been maximal in utilizing existing technology because of many factors so that innovations made in online learning mathematics are still limited.

The assessment done by teachers tend to the cognitive aspects by Minimum Completeness Criteria (MCC) remains 75. The teachers give examination by using Google Forms. Moreover, the teachers are not more flexible in giving reward and punishment in the learning process during online learning.

Many students submit assignments not on time. The teacher calls them privately to go to school. However, when naughty students are called, they do not go to school. The teacher will usually trace it to his house and send the positive messages. Many obstacles were encountered in the completeness of documents and timeliness.

In addition, new problems arise when the learning process is online because the teacher are not able directly to monitor student in detail. The main cause are limited time, low communication and unclear learning material. Further research needs to be done to identify the obstacles that exist in the online learning process in other areas as a material for consideration in making policies by related parties

However, in the future, there will be a trend for using e-learning in the school. Teachers are required to be able to master it and then develop strategies or learning models according to the characteristics of the student and learning material.

\section{References}

\section{Book}

Mulyasa, Pengembangan Dan Implementasi Kurikulum 2013 (Bandung: PT Remaja Rosdakarya, 2013)

Zuriah, Nurul, 'Metodologi Penelitian Sosial Dan Pendidikan' (Jakarta: Bumi Aksara, 2006), 92

\section{Journal}

Aboagye, Emmanuel, Joseph Anthony Yawson, and Kofi Nyantakyi Appiah, 'COVID-19 and E-Learning: The Challenges of Students in Tertiary Institutions', Social Education Research, 2021, 1-8

Aini, Indrie Noor, and Nita Hidayati, 'Tahap Perkembangan Kognitif Matematika Siswa Smp Kelas VII Berdasarkan Teori Piaget Ditinjau dari Perbedaan Jenis Kelamin', Jurnal Penelitian Dan Pembelajaran $\begin{array}{lll}\text { Matematika, } & 10.2 \quad \text { (2017), } \quad 2-7\end{array}$ $<$ https://doi.org/10.30870/jppm.v10i2.2 027>

Al-Yasiri, Nidaa Muhammad Baqer, 'Effects of Using E-Learning as a Substitute for Traditional Education in the Time of Corona', Turkish Journal of Computer and Mathematics Education (TURCOMAT), 12.13 (2021), 3420-32

Cakir, Z, and H B Savas, 'A Mathematical Modelling Approach in the Spread of the Novel 2019 Coronavirus SARS-CoV-2 (Covid-19) Pandemic. Electron J Gen Med. 2020; 17 (4): Em205', 2020

Cucinotta, Domenico, and Maurizio Vanelli, 'WHO Declares Covid-19 a Pandemic', Acta Biomedica, 91.1 (2020), 157-60 
<https://doi.org/10.23750/abm.v91i1.9 397>

Dewi, Dara Puspita, Dinar Mediyani, Wahyu Hidayat, Euis Eti Rohaeti, and Tommy Tanu Wijaya, 'Analisis Kemampuan Berpikir Kritis Matematis Siswa SMP pada Materi Lingkaran dan Bangun Ruang Sisi Datar', JPMI Jurnal Pembelajaran Matematika Inovatif), 2.6 (2019), 371 $<$ https://doi.org/10.22460/jpmi.v2i6.p3 71-378>

Indaryani, Eka, and Dwi Suliworo, 'Dampak Pemanfaatan WhatsApp dalam Meningkatkan Motivasi Belajar Siswa pada Pelajaran Fisika', Prosiding Seminar Nasional Quantum, 25 (2018), 25-31

Iskandar, Resa, 'Penggunaan Grup Whatsapp Sebagai Media Pembelajaran terhadap Peserta Didik DTA At-Tawakal Kota Bandung', Comm-Edu (Community Education Journal), $\quad 3.2 \quad$ (2020), 97 $<$ https://doi.org/10.22460/commedu.v3i2.3778>

Juwantara, Ridho Agung, 'Analisis Teori Perkembangan Kognitif Piaget pada Tahap Anak Usia Operasional Konkret 712 Tahun Dalam Pembelajaran Matematika', Al-Adrka: Jurnal Ilmiah Pendidikan Guru Madrasab Ibtidaiyah, 9.1 (2019), <https://doi.org/10.18592/aladzkapgmi. v9i1.3011>

Kencanawaty, Gita, Chatarina Febriyanti, and Ari Irawan, 'Tantangan dan Strategi Pembelajaran Matematika di Masa Adaptasi Kebiasaan Baru (AKB) Dampak Dari Covid-19', Prosiding Seminar Nasional Dan Diskusi Panel Pendidikan Matematika, 58, 2020, 215-20

Khatimi, Husnul, 'Mengenal E-Learning Sebagai Salah Satu Bentuk Kegiatan Pembelajaran', Info Teknik, 7.2 (2006), 72 81

Kholiyanti, Arni, 'Pembelajaran Matematika dari Konkrit Ke Abstrak dalam Membangun Konsep Dasar Geometri bagi Siswa Sekolah Dasar', Pi: Mathematics Education Journal, 1.2 (2018), 40-46 <https://doi.org/10.21067/pmej.v1i2.23 $22>$

Mailizar, Abdulsalam Almanthari, Suci Maulina, and Sandra Bruce, 'Secondary
School Mathematics Teachers' Views on e-Learning Implementation Barriers during the Covid-19 Pandemic: The Case of Indonesia', Eurasia Journal of Mathematics, Science and Technology Education, 16.7

<https://doi.org/10.29333/EJMSTE/82 $40>$

Marinda, Leny, 'Teori Perkembangan Kognitif Jean Piaget dan Problematikanya pada Anak Usia Sekolah Dasar', An-Nisa': Jurnal Kajian Perempuan Dan Keislaman, 13.1 (2020) $116-52$ $<$ https://doi.org/10.35719/annisa.v13i1. $26>$

Maspaeni, 'Penerapan Quality Control dalam Upaya Meningkatkan Kualitas Pendidikan Melalui E-Learning', Jutisi, 6.1 (2017), 1311-1448

Melisa, Indah, 'Pengembangan Media Pembelajaran Berbasis E-Learning pada Mata Kuliah Perkembangan Peserta Didik di Jurusan Pendidikan Teknik Elektronika Universitas Negeri Makassar', Jurnal Program Studi Pendidikan Teknik Elektronika FT-UNM, 2019

Nadeem, Said, 'Coronavirus Covid-19: Available Free Literature Provided by Various Companies, Journals and Organizations Around the World', Journal of Ongoing Chemical Research, 5.1 (2020), 7 13

$<$ https://doi.org/10.5281/zenodo.37229 04>

Radha, Rajapandian, K Mahalakshmi, V Sathish Kumar, and A R Saravanakumar, 'ELearning during Lockdown of Covid-19 Pandemic: A Global Perspective', International Journal of Control and Automation, 13.4 (2020), 1088-99

Riyatuljannah, Triwahyu, and Suyadi Suyadi, 'Analisis Perkembangan Kognitif Siswa pada Pemahaman Konsep Matematika Kelas V SDN Maguwoharjo 1 Yogyakarta', EduHumaniora | Jurnal Pendidikan Dasar Kampus Cibiru, 12.1 (2020), 48-54 $<$ https://doi.org/10.17509/eh.v12i1.209 $06>$

Sahidillah, Muhammad Wildan, Prarasto Miftahurrisqi, Prodi Pendidikan, Bahasa 
Indonesia, Pascasarjana Universitas, and Sebelas Maret, 'Whatsapp Sebagai Media Literasi Digital Mahasiswa', Pendidikan Bahasa Indondesia P, 2011, 52-57

Sukaesih, P., and E. Nugraha, 'Go-Study Electronic Learning Service Application', IOP Conference Series: Materials Science and Engineering, $\quad 407.1$

<https://doi.org/10.1088/1757899X/407/1/012036>

Tanu Wijaya, Tommy, Zhou Ying, Siti Chotimah, Martin Bernard, Zulfah, and Astuti, 'Hawgent Dynamic Mathematic Software as Mathematics Learning Media for Teaching Quadratic Functions', Journal of Physics: Conference Series, 1592.1 (2020) <https://doi.org/10.1088/17426596/1592/1/012079>

Toipur, 'Pentingnya Penilaian Kemampuan Matematika yang Berbasis pada Proses Pembelajaran', Jurnal Math Educator Nusantara, 03.76 (2017), 1-57

Trgalová, Jana, Alison Clark-Wilson, and HansGeorg Weigand, 'Technology and Resources in Mathematics Education', Developing Research in Mathematics Education, 2018, 142-61 $<$ https://doi.org/10.4324/97813151135 $62-12>$
Trianto ibnu badar Al-Tabany, 'Mendesain Model Pembelajaran Inovatif, Progresif, Kontekstual', 2017, 314

Uegatani, Yusuke, Nagisa Nakawa, and Masato Kosaka, 'Changes to Tenth-Grade Japanese Students' Identities in Mathematics Learning During the Covid19 Pandemic', International Electronic Journal of Mathematics Education, 16.2 (2021), em0638

Whildan, Lissya, 'Analisis Teori Perkembangan Kognisi Manusia Menurut Jean Piaget', Permata: Jurnal Pendidikan Agama Islam, 2.1 (2021), 11-22

Wijaya, Tommy Tanu, Zhou Ying, and Lin Suan, 'Gender and Self Regulated Learning During Covid-19 Pandemic in Indonesia', Jurnal Basicedu, 4.3 (2020), 725 32

$<$ https://doi.org/10.31004/basicedu.v4i $3.422>$

Wiranota, H., and T. T. Wijaya, 'The International Students' Perception towards Online Learning Using the Tencent Meeting during Covid-19 Outbreak', Journal of Physics: Conference Series, $\quad 1823.1$ $<$ https://doi.org/10.1088/17426596/1823/1/012011> 